G.V. Bezprozvannych, A.G. Kyessayev, I.A. Mirchuk, A.V. Roginskiy

\title{
IDENTIFICATION OF TECHNOLOGICAL DEFECTS IN HIGH-VOLTAGE SOLID INSULATION OF ELECTRICAL INSULATION STRUCTURES ON THE CHARACTERISTICS OF PARTIAL DISCHARGES
}

Introduction. High-voltage insulation systems always have some background level of the partial discharges, which does not have
any significant effect on the life of the electrical insulation design. At the same time, partial discharges destroy high-voltage
insulation, leading to a carburization zone around the defect. This is the "hidden" period of development of the defect. The
development of a defect zone, sooner or later, leads to an arc breakdown of the entire insulating gap. Purpose. The substantiation
of the efficiency of detection of technological defects in high-voltage solid insulation of electrical insulating structures according
to the characteristics of partial discharges. Methodology. The conditions for the occurrence of partial discharges in the thickness
of the polymer insulation are considered. The possible values of the voltage of the beginning of partial discharges are determined
for a model of a cylindrical air gap near the conductor of a power cable. It is shown that with the same applied voltages to high-
voltage insulation, in the latter case, air inclusions of smaller thickness are activated in comparison with a flat structure.
Practical value. The efficiency of detection of technological defects in solid composite case insulation of the stator winding of
turbo- and hydrogenerators is shown. Based on the comparison of the amplitude of the pulses of partial discharges of positive and
negative polarity, the estimated location of the technological defects in the insulation has been established. References 19,
figures 7 , table 1 . Key words: technological defects, partial discharges, voltage of the start of partial discharges, glass-mica paper tape, amplitude of pulses of partial discharges, location of the defect.

Визначено можливі значення напруги початку часткових розрядів для моделі циліндричного повітряного зазору поблизу струмопровідної жсили силового кабелю. Показано, щчо при однакових прикладених напругах до високовольтної ізоляції в останньому випадку активізуються повітряні включення менщої товщини в порівнянні 3 пласкою конструкцією. На підставі результатів проведених випробувань силового кабелю на напругу 3 кВ встановлено, щцо грубі технологічні дефекти в товщі ізоляцї̈ відсутні. Амплітуда розрядів в повітряних включеннях не перевищує 10 пКл при прикладеній випробувальній напрузі 5 кВ частоти 50 Гц. Показана ефективність виявлення технологічних дефектів у твердої композитної корпусної ізоляції обмотки статора турбо- $i$ гідрогенераторів. Встановлено, щц в макетах, ізоляція яких виконана стрічками меншої товщини, технологічні дефекти розташовані в товщі ізоляції. Для макета, ізоляція якого виконана стрічками більщої товщини, технологічні дефекти у вигляді розщарування розташовані на кордоні розділу провідник - композитна ізоляція. Бібл. 19, табл. 1, рис. 7.

Ключові слова: технологічні дефекти, часткові розряди, напруга початку часткових розрядів, склослюдопаперова стрічка, амплітуда імпульсів часткових розрядів, місце розташування дефекту.

Определены возможные значения напряжения начала частичных разрядов для модели цилиндрического воздушного зазора вблизи токопроводящей жилы силового кабеля. Показано, что при одинаковых приложенных напряжениях к высоковольтной изоляции в последнем случае активизируются воздушные включения меньшей толщины в сравнении с плоской конструкцией. На основании результатов проведенных испытаний силового кабеля на напряжсение 3 кВ установлено, что грубые технологические дефекты в толще изоляции отсутствуют. Амплитуда разрядов в воздушных включениях не превыщает 10 пКл при приложенном испытательном напряжении 5 кВ частоты 50 Гц. Показана эффективность выявления технологических дефектов в твердой композитной корпусной изоляции статорной обмотки турбо- и гидрогенераторов. Установлено, что в макетах, изоляция которых выполнена лентами меньшей толщины, технологические дефекты расположены в толще изоляции. Для макета, изоляция которого выполнена лентами большей толщины, технологические дефекты в виде расслоения расположены на границе раздела проводник-композитная изоляция. Библ. 19, табл. 1, рис. 7.

Ключевые слова: технологические дефекты, частичные разряды, напряжение начала частичных разрядов, стеклослюдобумажная лента, амплитуда импульсов частичных разрядов, место расположения дефекта.

Introduction. The most typical defects in solid high-voltage insulation during the production of electrical insulating structures are air inclusions. The reason for their occurrence in the thickness of the insulation may be manufacturing errors. For example, in power cables insufficient drying of polymer granules before loading them into the extruder or the insulation cooling rate at the exit from the extruder is too high [1-3].

Internal gas inclusions during the process of vacuum-injection impregnation and baking are inevitably present in thermosetting insulation systems based on mica tapes used in high-voltage electrical machines. As a rule, each electric machine manufacturer uses its own design and manufacturing technology for coil and cabinet highvoltage insulation, which differs from other manufacturers in the types and thickness of materials used, in the number of layers and total insulation thickness, in duration and value of temperature effects during its manufacture [4 -6].

When operating under high voltage of power frequency of high voltage solid insulation, in air

(c) G.V. Bezprozvannych, A.G. Kyessayev, I.A. Mirchuk, A.V. Roginskiy 
inclusions partial discharges (PDs) occur. High-voltage insulation systems always have some background level of the PD, which does not have any significant effect on the life of the electrical insulation design. At the same time, partial discharges destroy high-voltage insulation, leading to a carburization of the zone around the defect. This is the «hidden» period of development of the defect. The development of a defect zone, sooner or later, leads to an arc breakdown of the entire insulating gap.

The goal of the paper is substantiation of the efficiency of detection of technological defects in highvoltage solid insulation of electrical insulating structures according to the characteristics of partial discharges.

Problem definition. For partial discharges there are no standard normalized values. The existing local norms and recommendations are valid only for small groups of electrical insulating structures [7, 8]. For this reason, in most cases, a quantitative assessment of the state of the insulation of electrical machines using partial discharge parameters can be made only by comparison with the results of previous measurements performed on the same equipment $[9,10]$.

For power cables with cross-linked polyethylene insulation, measurements of PD characteristics are performed with a smooth rise of the test voltage to twice the operating voltage of the power frequency for 10 seconds, and then slowly decrease to 1.73 from the nominal value [11]. PD level should not exceed $10 \mathrm{pC}$.

Partial discharges are characterized by the following parameters: voltage of the beginning of the PD; apparent charge amplitude; frequency of pulses of PD. In modern diagnostic systems, the following are used: maximum amplitude of partial discharge pulses of positive and negative polarity, measured in millivolts $(\mathrm{mV})$; level of $\mathrm{PD}$ of positive and negative polarity ( $\mathrm{pC}$ ); amplitudephase diagrams of PD pulses (dependence of the number of discharges with specific values of the apparent charge on the voltage phase of the power frequency - the socalled PD-diagrams) [7-10, 12-19].

The connection of the start of partial discharges with the thickness of the air inclusions. Suppose that in the insulation layer with thickness $h$ there is an air inclusion with thickness $x$ (Fig. 1,b). For quality insulation, usually $x<<$ [18].

In Fig. 1 the following is indicated: $x$ - the thickness of air inclusion in the insulation; $h$ - the thickness of the insulation; $\varepsilon$ - the dielectric permeability of the dielectric, $C_{x}$ - the inclusion capacitance; $C_{h-x}$ - the capacitance of the insulation part opposite the inclusion; $C_{0}-$ the capacitance of the rest of the insulation [18].

Let us determine what part $U_{x}$ of external voltage $U$ falls on inclusion with thickness $x$ (Fig. 1,b).

Inclusion capacitance is defined as

$$
C_{x}=\varepsilon_{0} S_{x} / x,
$$

where $\varepsilon_{0}$ is the dielectric constant $\left(\varepsilon_{0}=8,85 \cdot 10^{-12} \mathrm{~F} / \mathrm{m}\right)$; $S_{x}$ is the inclusion area, $\mathrm{m}^{2}$.

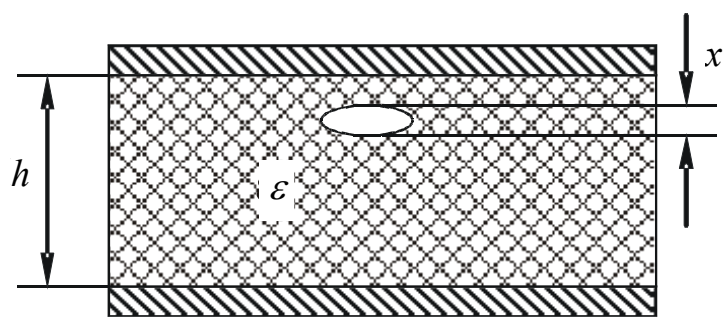

a

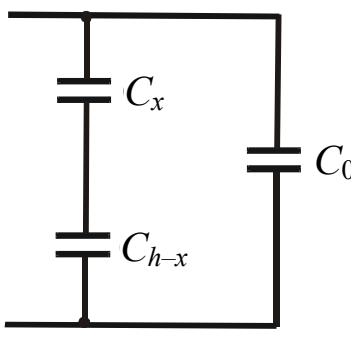

$b$

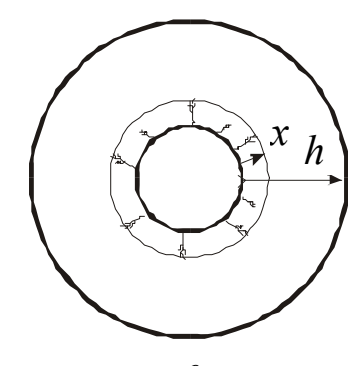

$c$
Fig. 1. Flat (a) and cylindrical (c) models for calculating the voltage of the beginning of the PDs on the basis of a capacitive replacement circuit $(b)$ of insulation

Capacitance of a continuous dielectric layer located opposite the inclusion

$$
C_{h-x}=\varepsilon \varepsilon_{0} S_{x} /(h-x) .
$$

From the capacitive replacement circuit (Fig. 1,b) we find $U_{x}$

$$
U_{x}=U \frac{1 /\left(\omega C_{x}\right)}{1 /\left(\omega C_{x}\right)+1 /\left(\omega C_{h-x}\right)}=U \frac{\varepsilon x}{h+(\varepsilon-1) x} .
$$

At $x \rightarrow 0$, the voltage on the inclusion tends to zero $U_{x} \rightarrow 0$ (because its own capacitance increases indefinitely), at $x \rightarrow h$ all external voltage falls on the inclusion $U_{x} \rightarrow U$ (because the inclusion takes up the entire insulating gap).

When the voltage on the inclusion reaches the level of the breakdown voltage $U_{x b r}$ the inclusion breaks through

$$
U_{x} \geq U_{x b r} .
$$

Since here only part $x$ of the insulating gap $h$ breaks through, the discharge is accordingly called partial. The corresponding voltage on the electrodes, at which the condition (4) begins to be fulfilled, is the voltage of the beginning of the PD [12-18].

The breakdown voltage $U_{x b r}$ of inclusion depends on its thickness $x$. This experimental relationship (Paschen curve) is shown in Fig. 2, curve 1. As the thickness $x$ decreases, the breakdown voltage decreases and at $x=7 \mu \mathrm{m}$ it reaches a minimum of $U_{x b r}=320 \mathrm{~V}$ ampl. $=226 \mathrm{~V}$ eff., and then even increases slightly [18]. In accordance with the empirical Paschen law, the breakdown voltage of the gas gap is a function of the product of pressure $p$ and thickness $x$ : $U_{x b r}=U_{x b r}(p x)$.

Consider the conditions of occurrence of PD in the thickness of the insulation. The results of calculations according to (1) - (3) are shown in Fig. 2,a (curves $2-4$ ) and Fig. 2,b (curves $2-5$ ). 

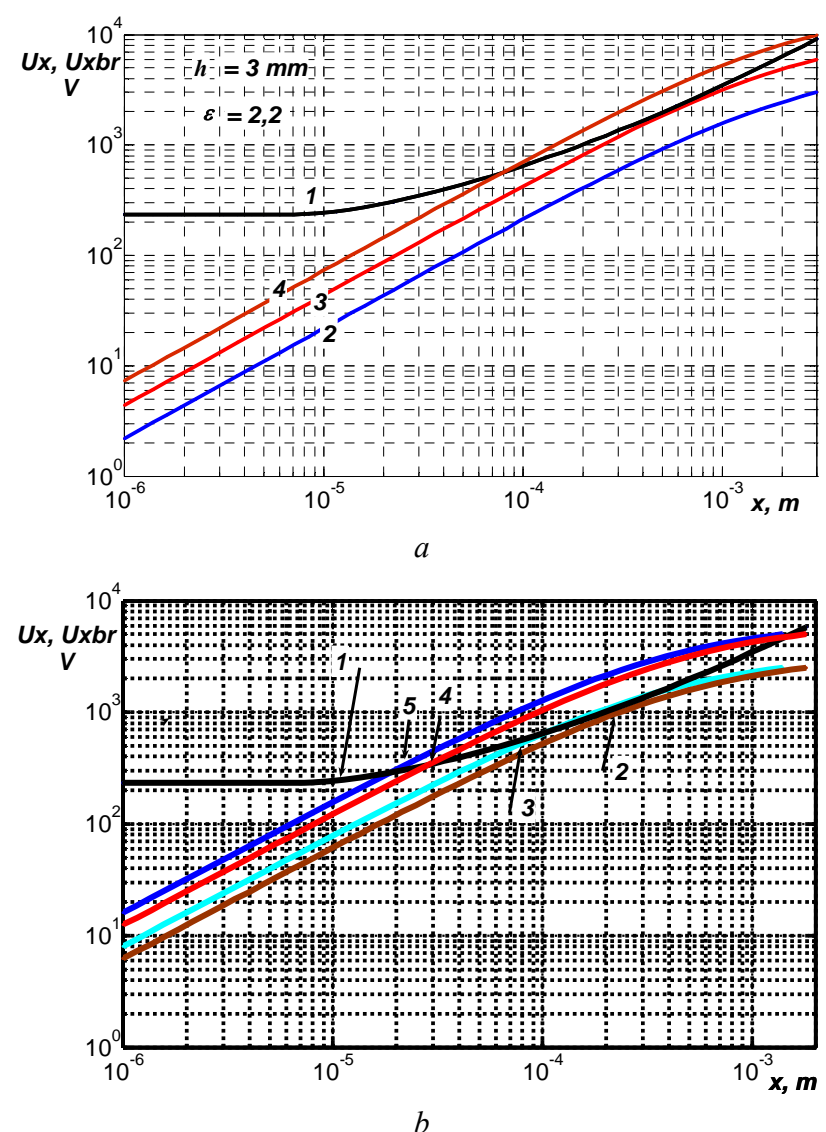

Fig. 2. Dependencies on the thickness ( $x$ ) of the air inclusion of its breakdown voltage $U_{x b r}$ and the calculated voltages $U_{x}$ on the inclusions

Insulation voltages (Fig. 2,a): $2.5 \mathrm{kV}$ (curve 2), $5 \mathrm{kV}$ (curve 3) and $10 \mathrm{kV}$ (curve 4). Insulation thickness $h=3 \mathrm{~mm}$, dielectric permeability $\varepsilon=2.2$ (polyethylene non-polar insulation of power cables). At voltage of $2.5 \mathrm{kV}$, the PDs are impossible in insulation (Fig. 2,a): curve $2-U_{x}(x)$ lies below curve 1 of the breakdown voltage of air inclusions. At voltage of $5 \mathrm{kV}$, the PDs in insulation are possible if it contains $0.6 \mathrm{~mm}$ thick air inclusions (intersection of curves 3 and 1). At voltage of $10 \mathrm{kV}$ PDs in insulation are possible if it contains air inclusions with a thickness of 0.08 to $3 \mathrm{~mm}$. Note that these are very large inclusions compared with a dielectric thickness of $3 \mathrm{~mm}$. Measurement of the PDs allows to detect the presence of very coarse defects in the insulation.

Insulation voltages (Fig. 2,b): $2.5 \mathrm{kV}$ (curve 2), $5 \mathrm{kV}$ (curve 4) for an insulation thickness of $1.8 \mathrm{~mm} ; 2.5 \mathrm{kV}$ (curve 3 ) and $5 \mathrm{kV}$ (curve 5) for an insulation thickness of $1.4 \mathrm{~mm}$, respectively. The dielectric permeability is $\varepsilon=4.5$ (characteristic values for composite glass-mica insulation of electrical machines). At voltage of $5 \mathrm{kV}$ PDs in insulation with a thickness of $1.8 \mathrm{~mm}$ are possible if it has air inclusions with a thickness of $0.03 \mathrm{~mm}$ and more, i.e. from $30 \mu \mathrm{s}$ (see Fig. 2,b, curve 4). For thinner composite insulation $(1.4 \mathrm{~mm})$ at applied voltage of $5 \mathrm{kV}$, air inclusions with a thickness of $20 \mu \mathrm{m}$ and more are activated (see Fig. 2,b, curve 5).
Figure 3 shows the effect of the dielectric permeability of composite insulation with a thickness of $1.8 \mathrm{~mm}$ on the calculated voltages $U_{x}$ on inclusions. Curve 2 corresponds to $\varepsilon=4.5$; curve 3 - to $\varepsilon=4.8$ for the same value of the applied voltage, equal to $5 \mathrm{kV}$. Increasing the dielectric permeability of composite insulation, i.e. the proportion of mica leads to a shift of the $U_{x}(x)$ curve to the region of smaller values of activated air inclusions (see curve 3 in Fig. 3).

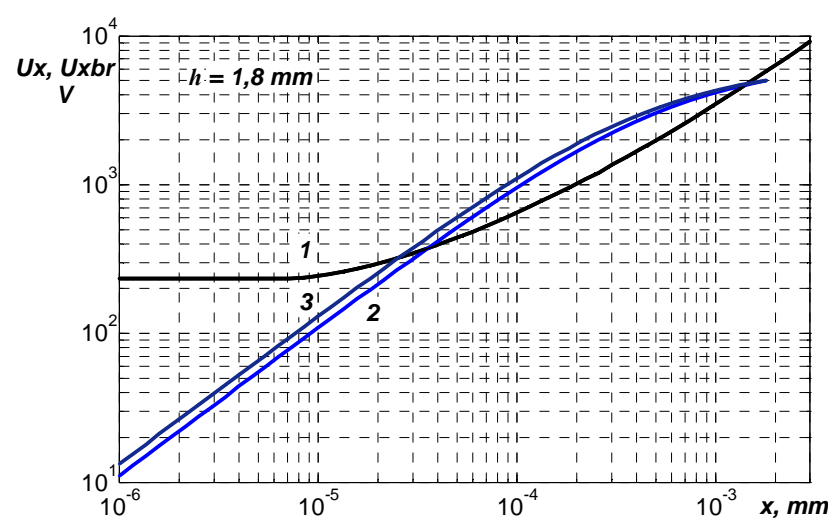

Fig. 3. The effect of the dielectric permeability of composite insulation on the calculated voltages $U_{x}$ on air inclusions

The influence of the location of the defect on the voltage of the beginning of partial discharges in the power cable. In the process of cooling of extruded polymer insulation on a conductive core, the formation of internal voids in the thickness of the extruded insulation is possible. Here, the probability of formation of bubbles and voids near the core, whose temperature is higher in comparison with the outer layers of insulation, increases significantly [2]. It should be taken into account that the electric field strength near the core is also higher [18]. Let us determine the possible values of the voltage of the beginning of the PDs, using the model of a cylindrical air gap near the core (Fig. 1,c).

The results are presented in Fig. 4: the cross section of the conductive core is $25 \mathrm{~mm}^{2}$, the thickness of the polyethylene insulation is $3 \mathrm{~mm}, \varepsilon=2.2$.

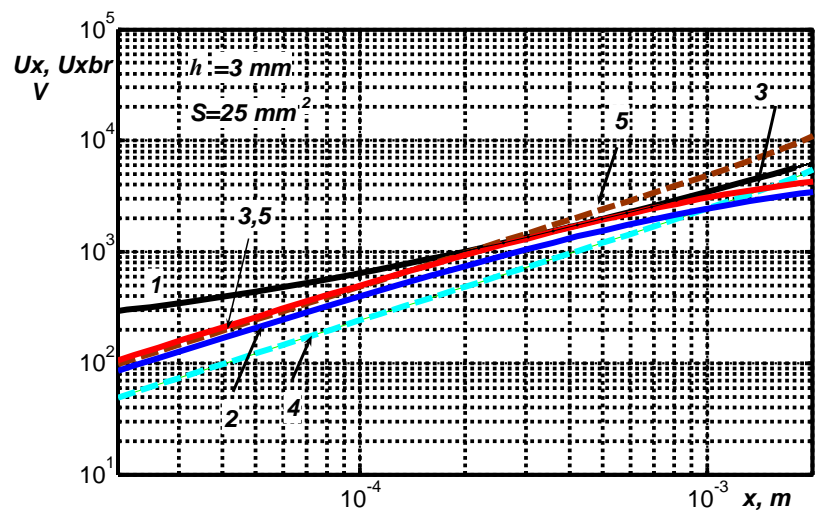

Fig. 4. The influence of the location of technological defect on the voltage of the beginning of the PDs in extruded power cable insulation 
Curve 1 - breakdown voltage $U_{x b r}$ of the inclusion; curves 2 and 3 correspond to the case of a technological air defect near the conductive core at 4 and $5 \mathrm{kV}$ on the insulation; curves 4 and 5 - when the air defect is located near the outer surface of the insulation at voltage of 5 and $10 \mathrm{kV}$ on the insulation, respectively. As the results of the calculation show, when applying the test voltage, technological defects located near the conductive core are activated first. When the voltage on the insulation is $5 \mathrm{kV}$, PDs arise in inclusions with a thickness of $200 \mu \mathrm{s}$. At voltage of $10 \mathrm{kV}$, air inclusions located near the insulation surface are not activated (see Fig. 4, curve 5).

Efficiency of detection of technological defects in solid insulation according to the characteristics of PDs. Figure 5 shows the PDs oscillogram in a sample of a power cable for voltage of $3 \mathrm{kV}$ (cross section of a conductive core $25 \mathrm{~mm}^{2}$, thickness of polyethylene insulation $3 \mathrm{~mm}$ ). In the thickness of the insulation there are air inclusions, which are activated at test voltage of $5 \mathrm{kV} 50 \mathrm{~Hz}$. The amplitude of the PDs does not exceed $10 \mathrm{pC}$, which corresponds to the requirements of the Standard [11]. It should be noted that at the operating voltage partial discharges in the cable do not occur.

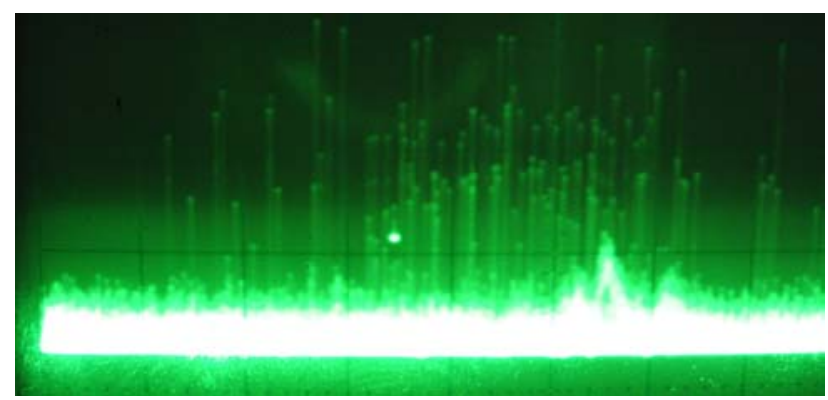

Fig. 5. PDs oscillogram in the thickness of the solid polyethylene insulation of the power cable (the mark in the center of the sweep is a calibration signal of amplitude $2 \mathrm{pC}$ )

Experimental studies on the detection of technological defects in high-voltage composite case insulation of the stator winding of the turbo- and hydrogenerators are carried out on 5 layouts of the same thickness. The insulation of the layouts is made of glassmica paper tapes of different thickness from different manufacturers (6 samples for each layout).

The PD monitoring method is based, for example, on the use of a portable analyzer with a set of epoxy-mica capacitors with a capacitance of $80 \mathrm{pF}$ as capacitive sensors, which allow measuring PDs in the high frequency range, in which the $\mathrm{PD}$ amplitude significantly exceeds the interference amplitude [8-10, 19]. This allows to automatically reliably separate the PDs and interference. The principle of the system operation is based on the detection of voltage pulses of partial discharges arising inside the insulation, using PD sensors, followed by their analog-digital conversion using a PD meter and displaying the PD amplitude of both positive and negative polarity. It should be taken into account that the maximum voltage of the PD pulse in $\mathrm{mV}$ is measured (see Fig. 5). The suppliers of relevant measuring equipment indicate the measured value not with a voltage symbol $(U)$, but with a charge symbol $(Q)$, assuming that there is an obvious connection between voltage and charge. The proportionality factor is the electrical capacitance of an insulation system, for example, a stator winding, which can always be measured.

An effective way to determine the state of the insulation system is to compare the results with the database [9. 10] presented in Table 1 .

Table 1

Evaluation of insulation by maximum PD pulse amplitude values

\begin{tabular}{|l|c|}
\hline PD category & PD pulse amplitude, $\mathrm{mV}$ \\
\hline Minor & $0-45$ \\
\hline Low & $46-98$ \\
\hline Typical & $99-210$ \\
\hline Moderate & $211-412$ \\
\hline
\end{tabular}

Figure 6 shows the results of measurements of the maximum amplitude of partial discharge pulses of positive and negative polarity in layouts with high-voltage solid composite insulation based on glass-mica paper tapes at voltage of $3.6 \mathrm{kV}$ (Fig. 6,a) and $6 \mathrm{kV}$ (Fig. 6,b).
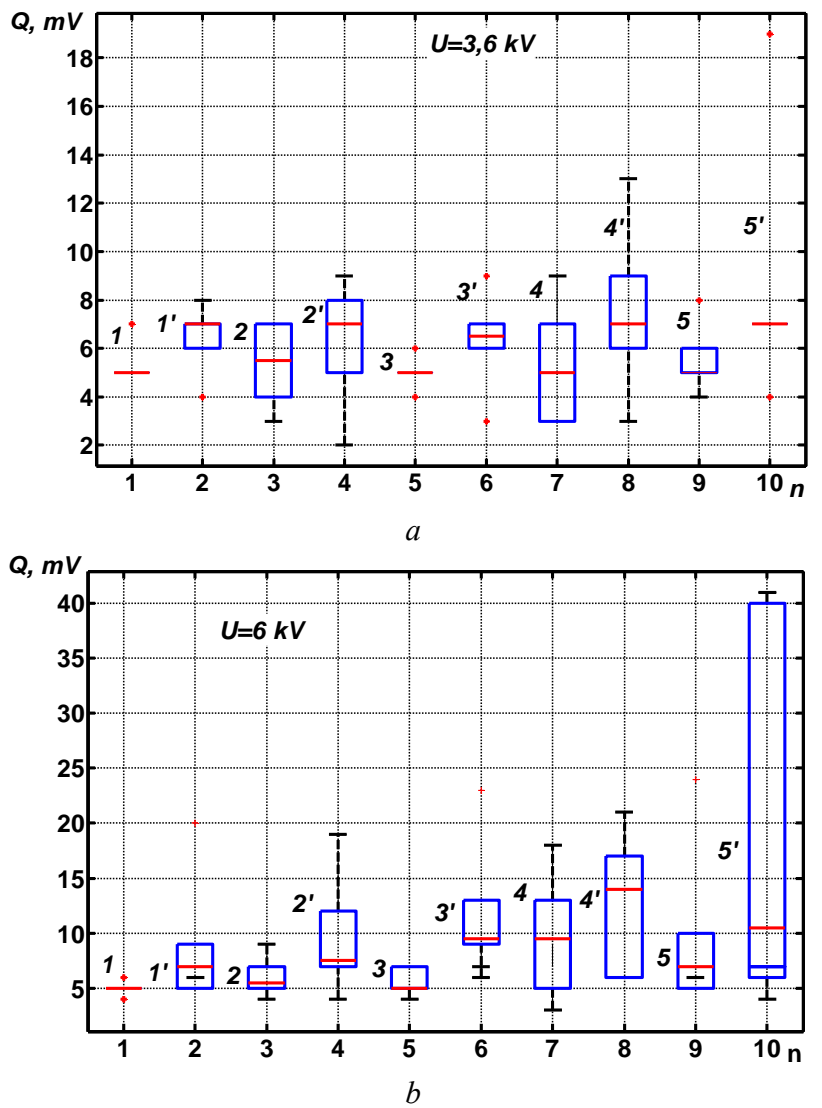

Fig. 6. The results of the statistical distribution of the maximum amplitude of partial discharge pulses depending on the applied voltage of power frequency in composite solid high-voltage insulation 
The thickness of the tapes: $1-h=0.14 \mathrm{~mm}, 2-$ $h=0.14 \mathrm{~mm}, 3-h=0.15 \mathrm{~mm}, 4-h=0.18 \mathrm{~mm}, 5-$ $h=0.18 \mathrm{~mm}$. The amplitude of the partial discharge pulses of positive polarity is denoted as $1,2, . ., 5$; the amplitude of the partial discharge pulses of negative polarity: 1', 2', ..., 5', respectively. PD pulses of negative polarity occur at a positive half-wave of the test voltage of power frequency, positive - at a negative half-wave of voltage.

Comparison of positive and negative PD pulses indicates that the discharges occur exactly inside the insulation for the layouts, the thickness of the tapes of which is less than $0.18 \mathrm{~mm}$ (Fig. 7,a). The amplitude of the discharges of positive and negative polarity is almost the same (compare 1 and 1', 2 and 2', 3 and 3', 4 and 4', Fig. 6,b). These results are consistent with the calculated dependencies (see Fig. 2,b and Fig. 3). For samples with glass-mica paper tape $0.18 \mathrm{~mm}$ thick, the amplitude of negative polarity pulses is almost 4 times higher than the amplitude of positive polarity pulses (compare 5 and 5 , Fig. 6,b).

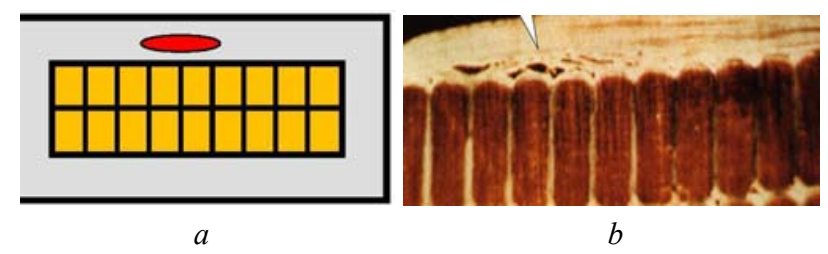

Fig. 7. The locations of technological defects in the composite insulation of the windings of electrical machines

Obviously, such a difference is due to the location of the technological defect in the form of a bundle at the interface between the conductor and composite insulation (Fig. 7,b). At voltage of $6 \mathrm{kV}$, the amplitude of the discharge pulses reaches an upper value of $40 \mathrm{mV}$ in the category of the PDs as a minor level (see Table 1).

Conclusions. The dependencies on the thickness of air inclusion of its breakdown voltage and calculated voltages on inclusions for a flat and cylindrical insulation model are obtained. At the same applied voltages to highvoltage insulation, in the latter case, air inclusions of smaller thickness are activated in comparison with the flat structure.

The possible values of the voltage of the beginning of partial discharges and the range of activated technological defects are determined depending on the location of the air inclusion in the structure of the power cable of a coaxial design.

The efficiency of detection of technological defects in solid high-voltage composite case insulation of the stator winding of turbo- and hydrogenerators is shown. Based on the comparison of the amplitude of the pulses of partial discharges of positive and negative polarity, the location of technological defects in the structure is determined.

The results of the studies confirm the efficiency of registration of partial discharges in high-voltage solid insulation for detecting defects at the technological stage of manufacturing of electrical insulating structures, as well as for setting up the technological process itself.

\section{REFERENCES}

1. Leonov V.M., Peshkov I.B., Ryazanov I.B., Kholodnyy S.D. Osnovy kabelnoy tehniki [Basics of cable technology]. Moscow, Akademiya Publ., 2006. 432 p. (Rus).

2. Bezprozvannych G.V., Mirchuk I.A., Kyessayev A.G. Technological parameters of the cooling mode of polymer insulation of power cables. Electrical engineering \& electromechanics, 2019, no.3, pp. 44-49. doi: 10.20998/2074272X.2019.3.07.

3. Rao Natti S., Shott Nik R. Tekhnologicheskie raschety $v$ pererabotke plastmass [Technological calculations in plastics processing]. Saint Petersburg, Professiya Publ., 2013. 200 p. (Rus).

4. Ogonkov V.G., Serebryannikov S.V. Elektroizoliatsionnye materialy $i$ sistemy izoliatsii dlia elektricheskikh mashin. $V$ dvukh knigakh. Kn. 2 [Electrical insulation materials and insulation systems for electrical machines. In 2 books. Book 2]. Moscow, Publishing house MEI, 2012. 304 p. (Rus).

5. Pak V.M., Trubachev S.G. Novye materialy $i$ sistemy izoliatsii vysokovol'tnykh elektricheskikh mashin [New materials and systems for isolation of high-voltage electrical machines]. Moscow, Energoatomizdat Publ., 2007. 416 p. (Rus).

6. Bezprozvannych G.V., Boyko A.N., Roginskiy A.V. Effect of a dielectric barrier on the electric field distribution in highvoltage composite insulation of electric machines. Electrical engineering \& electromechanics, 2018, no.6, pp. 63-67. doi: 10.20998/2074-272X.2018.6.09.

7. IEEE Standards 1434. Guide for the measurement of partial discharges in AC electric machinery. IEEE Park Avenue, New York, USA. 2014. 89 p.

8. CIGRE Working Group A1.01.06 Application. Of on-line partial discharge tests to rotating machines. CIGRE. December 2010.58 p.

9. Iris Power TGA-BTM. Periodic On-line Partial Discharge Monitoring Using a Portable Instrument for Motors and High Speed Turbine Generators. Iris Power Ver 5. 08/10. Canada, 2010.

10. Interpretation of $P D$ results - on-line testing. Version 3.2 Iris QMS 08/10. Ver. 3.2. 2008.

11. Shidlovsky A.K., Shcherba A.A., Zolotarev V.M., Podoltsev A.D., Kucheryavaya I.N. Kabeli s polimernoi izoliatsiei na sverkhvysokie napriazheniia [Polymer insulation cables for ultra-high voltages]. Kyiv, IED of NASU Publ., 2013. 552 p. (Rus).

12. Kuchinsky G.S. Chastichnye razriady v vysokovol'tnykh konstruktsiiakh [Partial discharges in high voltage structures]. Leningrad, Energiia Publ., 1979. (Rus).

13. Vdoviko V.P. Chastichnye razriady $v$ diagnostirovanii vysokovol'tnogo oborudovaniia [Partial discharges in diagnosing high-voltage equipment]. Novosibirsk, Nauka Publ., 2007. 55 p. (Rus).

14. Naboka B.G., Bezprozvannych G.V., Gladchenko V.Ya. Method of measuring the differential amplitude spectra of partial discharge pulses. Electricity, 1990, no.1, pp. 71-74. (Rus).

15. Naboka B.G., Bezprozvannych G.V., Gladchenko V.Ya. Diagnostics of high-voltage insulation using multichannel analyzers. Electricity, 1991, no.5, pp. 5-9. (Rus).

16. Bezprozvannych G. V., Kessaev A. G. Analysis of the field structure and justification of the diagnostics voltage for partial insulation discharges of shielded twisted pairs. Electrical 
engineering \& electromechanics, 2014, no.6, pp. 61-65. (Rus). doi: 10.20998/2074-272X.2014.6.11.

17. Bezprozvannych A.V. Ways of representation of differential peak spectra of pulses of partial discharges in solid insulation. Technical electrodynamics, 2011, no.4, pp. 12-19. (Rus).

18. Bezprozvannych A.V. High electric field and partial discharges in bundled cables. Technical electrodynamics, 2010, no.1, pp. 23-29. (Rus).

19. IEC Standard 60270. High-voltage test techniques - Partial discharge measurements. IEC, 2000. $55 \mathrm{p}$.

Received 05.04.2019

G.V. Bezprozvannych ${ }^{1}$, Doctor of Technical Science, Professor, A.G. Kyessayev ${ }^{1}$, Candidate of Technical Science,

I.A. Mirchuk ${ }^{2}$, Postgraduate Student,

A.V. Roginskiy ${ }^{3}$, Postgraduate Student,
${ }^{1}$ National Technical University «Kharkiv Polytechnic Institute», 2, Kyrpychova Str., Kharkiv, 61002, Ukraine, phone +380 577076010 , e-mail: bezprozvannych@kpi.kharkov.ua

${ }^{2}$ Private Joint Stock Company «Ukraine Scientific-Research Institute of Cable Industry»,

2-P, Promychlennaya Str., Berdyansk, Zaporozhye Region, 71101, Ukraine,

phone +380668288554 ,

e-mail: garik710@ukr.net

${ }^{3}$ SE Plant Electrotyazhmash,

299, Moskovsky Ave., Kharkiv, 61089, Ukraine, e-mail: roginskiy.av@gmail.com

How to cite this article:

Bezprozvannych G.V., Kyessayev A.G., Mirchuk I.A., Roginskiy A.V. Identification of technological defects in highvoltage solid insulation of electrical insulation structures on the characteristics of partial discharges. Electrical engineering \& electromechanics, 2019, no.4, pp. 53-58. doi: 10.20998/2074-272X.2019.4.08. 